Teologia i Moralność, volumen 12(2017), numer 2(22)

doi: 10.14746/tim.2017.22.2.5

\author{
MACIEJ OLCZYK \\ Uniwersytet im. Adama Mickiewicza w Poznaniu \\ Wydział Teologiczny
}

\title{
Kobieta i mężczyzna kustoszami Ewangelii życia w kontekście społecznego eksperymentu gender
}

Ewangelia życia to tytuł encykliki Jana Pawła II poświęconej wartości i nienaruszalności ludzkiego życia ${ }^{1}$. Wieloznaczność tego tytułowego wyrażenia zwraca uwagę na bogactwo kryjących się w nim treści. Całe przesłanie ewangeliczne to wielka apoteoza życia: objawienie życia Bożego, ukazanie pełni życia, do jakiego powołany jest człowiek, wreszcie manifestacja triumfu życia nad śmiercią i zapewnienie o jego wiecznej trwałości. Ewangelia, czyli Dobra Nowina przyniesiona przez Jezusa Chrystusa, dotyczy przede wszystkim życia człowieka: odsłania, że ma ono swoją ,ponadorganiczną” głębię i wzniosłość. Ewangelia życia to dobra nowina o tym, że życiem człowieka opiekuje się Bóg i włącza je w swoje boskie, wieczne istnienie. $Z$ tego faktu życie człowieka czerpie swą godność i nienaruszalność. Dobra nowina wpisana jest także w naturę życia jako takiego. Istnieje nie tylko Ewangelia o życiu i dla życia, lecz w nieco poetycki sposób można by rzec, że samo życie jako dar pochodzący od Boga jest Ewangelią. Dziejące się życie jest swego rodzaju dobrą nowiną: z woli Boga ma ono znamiona trwałości, ciągle się odtwarza i rodzi na nowo, objawiając w ten sposób naturę Stwórcy, który jest Istnieniem i Miłośnikiem życia (por. Mdr 11,26). Innym jeszcze aspektem dobrej nowiny o życiu jest również i to, że Bóg podzielił się z człowiekiem w wyjątkowy ${ }^{2}$ sposób władzą nad życiem, powierzając kobiecie oraz mężczyźnie misję od-

\footnotetext{
${ }^{1}$ Por. Jan Paweł II, Encyklika Evangelium vitae, Kraków 1995 (dalej: EV).

2 Wyjątkowość ta polega m.in. na osobowym zaangażowaniu się człowieka w procesy przekazywania życia, co oznacza, że w akcie prokreacyjnym aktywny jest cały człowiek w jego cielesno-duchowej naturze i jako taki, świadomy i kochający, powołany jest do współdziałania z Bogiem powołującym do istnienia nową istotę ludzką.
} 
powiedzialnego pielęgnowania i rozwoju życia ${ }^{3}$. Uczynił ich swoistymi kustoszami Ewangelii życia i kustodiami daru istnienia.

Tej właśnie niezastąpionej roli kobiety i mężczyzny jako kustoszy Ewangelii życia poświęcimy niniejszą refleksję. Zadanie to domaga się dziś szczególnego przypomnienia, gdyż manifestująca się w wielorakich atakach na życie cywilizacja śmierci znalazła ciemnego sprzymierzeńca w nowej ideologii niszczącej podstawowe środowisko przekazywania życia, jakim jest więź miłości mężczyzny i kobiety. Wyrafinowany i przemyślany zabieg deprecjonowania i stopniowej eliminacji doniosłości biologicznych determinant płci na rzecz wykreowanej nowej kategorii, tzw. płci kulturowej (gender), może bez cienia wątpliwości zostać wpisany na listę wymienianych przez Jana Pawła II groźnych tendencji, które przez propagowanie niemoralnych wzorców zachowań w dziedzinie życia płciowego rodzą poważne niebezpieczeństwa dla życia ${ }^{4}$.

W niniejszym opracowaniu nie chodzi nam jednak tylko o wskazanie dawnych lub nowych zagrożeń dla ludzkiego życia, lecz o zaproponowanie refleksji, która wychodząc od fenomenu życia, pozwoli w jego świetle odkrywać ,życiodajny” sens kobiecości i męskości. Sądzimy bowiem, że zrozumienie ludzkiego życia jako złożonego procesu cielesno-psycho-duchowego pomaga właściwie zrozumieć istotę i znaczenie płci. Nasza refleksja zawierać będzie trzy etapy:

1) Najpierw przyjrzymy się wielowymiarowości ludzkiego życia, jaka wyłania się z antropologii biblijnej, będącej fundamentem dla etycznych rozstrzygnięć encykliki Evangelium vitae.

2) Następnie zobaczymy, w jaki sposób Bóg powierzył ludziom zadanie otaczania troską daru życia i pielęgnowania go.

3) W ostatniej części będziemy mogli przekonać się, jak bardzo większość tez ideologii gender sprzecznych jest z Ewangelią życia i tym samym stanowi zagrożenie dla życia ludzkiego.

\section{1. Życie człowieka w świetle antropologii biblijnej}

Jednym z najbardziej doniosłych pytań, któremu nauka poświęca rozległą paletę badań, jest pytanie: Czym jest życie? Kiedy podejmujemy refleksję nad Ewangelią życia, nie sposób uciec od tego fundamentalnego zagadnienia dotyczącego istoty życia jako takiego. Odpowiedź na to kluczowe pytanie nie jest

\footnotetext{
${ }^{3}$ Por. EV 34.

${ }^{4}$ Por. EV 10.
} 
prosta, jest raczej wieloaspektowa, angażuje wiele dyscyplin wiedzy przyrodniczej, filozoficznej, teologicznej. W kontekście dominującej dziś tendencji do materialistycznego wyjaśniania fenomenu życia warto może przypomnieć poglądy niemieckiego filozofa XX wieku Hansa Jonasa, który usiłował wykazać niewystarczalność prób wyjaśniania, czym jest życie, przy wykorzystaniu wyłącznie pojęcia świata nieożywionego. Jego zdaniem, fenomenu życia, a tym bardziej życia ludzkiego, nie można wyjaśniać kategoriami, które pozbawione są życia. Fizykalno-chemiczna analiza życia, ograniczona do jego materialnych wymiarów, nie prowadzi do pełniejszego zrozumienia, czym one jest. Co więcej, tego typu paradygmat, sprowadzający fenomeny świadomości, podmiotowości i wolności do faktów materialnych, może niestety prowadzić do coraz większego zaniku szacunku dla życia ludzkiego ${ }^{5}$. Nie dziwi zatem, że Jan Paweł II w encyklice Evangelium vitae rozważał tajemnicę ludzkiego życia w zdecydowanie odmiennej perspektywie. Papież postulował konieczność wyjścia poza ograniczenia redukcjonizmu materialistycznego, który eliminując wrażliwość na Boga i świat duchowy, osłabia w konsekwencji wrażliwość na samego człowieka ${ }^{6}$, prowadząc do upowszechniania się postaw indywidualistycznych, utylitarystycznych i hedonistycznych, leżących u podstaw wielu współczesnych zamachów na życie ludzkie ${ }^{7}$.

Jan Paweł II, podejmując w Evangelium vitae refleksję nad życiem ludzkim, osadził je przede wszystkim w perspektywie chrystologicznej: to w Jezusie Chrystusie w pełni objawiło się życie (por. $1 \mathrm{~J}$ 1,2). Pragnący pochylić się nad tajemnicą życia człowieka chrześcijanin powinien zatem skierować swe spojrzenie ku Chrystusowi ${ }^{8}$. W Nim bowiem zostaje nam ukazana pełnia życia zaofiarowana przez Boga człowiekowi. „W Jezusie, «Słowie życia» powiedził Jan Paweł II - zostaje nam zapowiedziane i udzielone życie Boże i wieczne. Dzięki temu objawieniu i temu obdarowaniu fizyczne i duchowe życie człowieka, także w swoim stadium ziemskim, zyskuje pełną wartość i znaczenie".

Przytoczona powyżej wypowiedź papieska, choć zasadniczo koncentruje się na centralnej roli Chrystusa przynoszącego człowiekowi życie nadprzyrodzone, wspomina przy okazji o dwóch innych wymiarach, w których urzeczywistnia się życie człowieka, a mianowicie o życiu fizycznym i życiu

${ }^{5}$ Por. E. Schockenhoff, Etyka życia. Podstawy i nowe wyzwania, thum. K. Glombik, Opole 2014, s. 60.

${ }^{6}$ Por. EV 22.

${ }^{7}$ Por. EV 23.

${ }^{8}$ Myśl ta biegnie paralelnie do przekonania wyrażonego w encyklice Redemptor hominis, wskazującej na kluczowe znaczenie spotkania z Chrystusem dla zrozumienia tajemnicy życia człowieka. Por. Jan Paweł II, Encyklika Redemptor hominis, Wrocław 1986, 10.

${ }^{9} \mathrm{EV} 30$. 
duchowym. W ten oto sposób papież nawiązał do podstawowych prawd antropologii biblijnej, ukazując życie człowieka jako rzeczywistość wielowymiarową, złożoną z przenikających się wzajemnie sfer, używając języka św. Pawła: ciała, duszy i ducha ${ }^{10}$. Te trzy kategorie antropologiczne, pochodzące bardziej ze świata filozofii greckiej, należałoby zestawić z paralelnymi do pewnego stopnia pojęciami semickimi, za pomocą których Biblia opisuje życie człowieka. Są nimi: basar, nefes i ruah ${ }^{11}$. Warto w tym miejscu zaznaczyć, że terminy te nie powinny być traktowane jako „części” czy „elementy” składowe człowieka, lecz raczej jako wymiary lub nurty, w których urzeczywistnia się ludzkie życie. Życie człowieka dzieje się i wyraża przez basar, nefes i ruah. W tych samych wymiarach jest też zagrożone ${ }^{12}$. Każde z tych pojęć określających człowieka „wyraża całość egzystencji ludzkiej z różnych punktów widzenia"13. Trzeba także pamiętać, że w myśli biblijnej życie jako takie nie jest wcale terminem pierwotnie antropologicznym czy zoologicznym, ale przysługuje wyłącznie Bogu ${ }^{14}$. Jedynie Bóg jest żywy i dzieli się życiem ze stworzeniami, pozwala żyć i utrzymuje przy życiu. Ten podstawowy fakt należy uwzględnić, aby właściwie zrozumieć pojęcia basar ${ }^{15}$, nefes ${ }^{16}$ i ruah ${ }^{17}$.

${ }^{10}$ Por. A. Muszala, Koncepcja czlowieka wedlug św. Pawła i jej implikacje dla bioetyki, w: K. Jasiński, Z. Kieliszek, M. Machinek, Mózg - umyst - dusza. Spór o adekwatna antropologię, Olsztyn 2014, s. 125-140.

11 Wnikliwą analizę tych pojęć przeprowadza w perspektywie antropologiczno-etycznej I. Mroczkowski, Starotestamentalne rozumienie ciała, duszy i ducha człowieka, „Studia Płockie” 21(1993), s. 17-24.

${ }^{12}$ Por. E. Bosetti, Il mistero della vita e la sua rivelazione nella Sacra Scrittura, w: Lo splendore della vita: Vangelo, scienza ed etica. Prospettive della bioetica a dieci anni da Evangelium vitae, red. L. Melina, E. Sgreccia, S. Kampowski, Città del Vaticano 2006, s. 38-39.

${ }^{13}$ I Mroczkowski, Starotestamentalne..., s. 22.

${ }^{14}$ Por. E. Bosetti, Il mistero..., s. 36-37.

${ }^{15}$ Basar - używane w języku biblijnym może mieć znaczenie „zbiorowe” jako 'wszelkie ciało' i wyrażać pewną całość istot żywych, w których płynie krew - znak życia (ludzie i zwierzęta). Chodzi więc zawsze o ciało żywe. Basar nigdy nie jest odniesione do Boga, przez co zawsze będzie określać życie stworzeń. Pojęcie to przypisane do pojedynczego człowieka służy określeniu kruchości, przemijalności i śmiertelności życia. Basar to nie tyle część składowa istoty ludzkiej, ile jeden z aspektów/nurtów życia człowieka. Basar oznacza zarówno całą strukturę życia organicznego naznaczonego śmiertelnością jak i tłumaczy słabość ludzkiej woli, która - zwłaszcza po grzechu pierworodnym - o własnych siłach z trudem podąża za dobrem. Co ważne - i co różni biblijną koncepcję basar od platońskiego rozumienia ciała jako „więzienia dla duszy” - to fakt, że kruchość i śmiertelność basar nie daje żadnych podstaw do postponowania lub negatywnej oceny materialnej sfery życia jako mniej wartościowej czy niegodnej. Wręcz przeciwnie, basar - wspólny wymiar życia zwierząt i ludzi - w przypadku człowieka otrzymuje od Boga ożywiające tchnienie życia, co podkreśla jego wyjątkową godność. Wyrazi to dosadnie Katechizm Kościoła katolickiego, przypominając, że „ciało ludzkie uczestniczy w godności obrazu Bożego” (KKK 364).

${ }^{16}$ Nefes - to biblijne pojęcie oddawane jest we współczesnych przekładach Pisma Świętego słowem 'dusza', Septuaginta tłumaczy je w większości przypadków jako psyche, a łacińskie przekłady posługują się wyrazem anima. Nefes nie jest pojęciem jednoznacznym. W Biblii czasem odnoszone jest tylko do ludzi, innym razem tylko do zwierząt, a czasami zarówno do ludzi, jak 
W świetle antropologii biblijnej, przyjętej jako fundament etycznych rozstrzygnięć encykliki Evangelium vitae, życie człowieka jawi się jako fenomen wielowymiarowy, zawiera w sobie aspekt fizyczny (basar), psychiczny (nefes) i duchowy (ruah). Można by je porównać do jednego strumienia równoległych nurtów dziejących się procesów, wzajemnie się przenikających i oddziałujących na siebie. Życie człowieka wyraża się - ale się nie wyczerpuje - w jego organicznych manifestacjach przemiany materii i innych procesach fizjologicznych. Jednocześnie ten sam strumień życia zawiera w sobie szerokie spektrum doświadczeń i przeżyć natury psychicznej, na który składają się

i do zwierząt. Pomijając w tym miejscu szczegółowe zawiłości interpretacyjne, należy podkreślić, że pewne jest to, iż biblijna antropologia pragnie ukazać człowieka, który nie tyle „ma” nefes, ile ,jest" nefes. Dusza jest wymiarem jego jestestwa, jego bytu, jest wyrazem jego życia. Życie człowieka wyraża się przez nefes, bo to właśnie słowo „dusza” wskazuje na istnienie żywego „ja”, które dąży i pożąda, pragnie i szuka, jest miejscem wzruszeń i poruszeń oraz wielu innych doznań natury psychicznej. Dlatego możemy w niej upatrywać nośnik stanów, które dzisiejszym językiem nazwalibyśmy przeżyciami psychicznymi. Nefes jest życiem psychicznym człowieka. Według opinii Otto Keisera biblijne nefes należy traktować jako ,indywidualne pryncypium życia albo ja, które czyni z człowieka osobę i określa jego niepowtarzalną odrębność. [...] Tak nefes reprezentuje całą osobę ludzką w jej trwającej aż do śmierci jedności cielesno-duchowej z punktu widzenia jej żywotności. Dlatego słowo to często można wprost przetłumaczyć jako życie" (O. Keiser, Der Gott des Alten Testaments: Wesen und Wirken. Theologie des AT 2, Göttingen 1998, s. 293. Tłumaczenie polskie cytuję za: Schockenhoff, Etyka..., s. 153).

${ }^{17}$ Ożywcze tchnienie pochodzące od Boga jest wyrażane w Biblii jeszcze innym pojęciem, gdy chce się podkreślić szczególnie odradzający czy wręcz wskrzeszający charakter więzi człowieka/ /stworzenia z Bogiem. Chodzi o słowo ruah, oznaczające zarówno Ducha Bożego, który u początków świata unosił się nad wodami (por. Rdz 1,2), jak i stwórcze tchnienie życia Bożego, które ma moc wskrzesić do życia wyschnięte kości, na nowo oblekając je ciałem i skórą, jak dzieje się to w wizji proroka Ezechiela (por. Ez 37,5n). W odniesieniu do człowieka ruah (gr. pneuma, łac. spiritus) występuje w Biblii często w związku z sercem jako najbardziej intymną przestrzenią przeżyć osobowych. W głębi ludzkiego jestestwa obok serca z ciała może bić inne serce - serce życia nadprzyrodzonego, życia będącego owocem życiodajnej więzi człowieka z Bogiem. Można by zaryzykować stwierdzenie, że o ile tchnienie nefes, też przecież pochodzące od Boga, zrodziło w człowieku puls życia psychicznego z adekwatną do niego behawiorystyką bodźcowo-emocjonalno-świadomościową, to ruah, przemienia te przeżycia mocą Bożą i zaszczepia w człowieku wyższy poziom egzystencji duchowej, będącej uczestnictwem w życiu samego Boga. Księga Rodzaju powie o takiej egzystencji, że jest to życie „na obraz i podobieństwo Boże” (por. Rdz 1,26), a Chrystus określi je jako życie wieczne, które ,polega na tym, że człowiek zostaje zrodzony przez Boga, aby mieć udział w pełni Jego miłości” (EV 37). W ten sposób wszyscy ludzie przyjmujący przez wiarę moc Słowa, które stało się ciałem i objawiło życie, mogą - jak powie św. Jan - stać się dziećmi Bożymi, narodzić się już nie tylko z ciała, krwi czy woli męża, ale z Boga (por. 1 J 1,12-13). Inspirowane i podtrzymywane przez ruah życie duchowe człowieka pozwala mu integrować własną osobowość, rozumnie kształtować wolę i ukierunkowywać pragnienia na autentyczne dobro poznawane dzięki światłu Ducha Świętego. W tym kontekście zaczynamy rozumieć właściwy sens formacji moralnej oraz doświadczenie sumienia. Ruah antropologii biblijnej odsłania przed nami ten wymiar ludzkiego życia, który jak powie Eberhard Schockenhoff wskazuje na „upoważnienie nowego, przez Ducha Bożego zainspirowanego człowieka [...]. Nie opowiada ono o naturalnych zaletach ludzi, ale o mocy Bożej, z której otrzymali oni swoje życie [fizyczne i czynią dobro]" (E. Schockenhoff, Etyka..., s. 154). 
reagowanie na bodźce, emocjonalność, uczuciowość, akty świadomości i akty woli właściwie życiu osobowemu. Wreszcie to samo życie otwiera się na perspektywę nieskończoności, gdy pozwala się ogarnąć miłością Boga, który ludzką egzystencję włącza w obieg własnego wewnątrztrynitarnego życia.

Tak rozumiane życie człowieka cieszy się wsobną godnością i nienaruszalnością. Jak przypomniał Jan Paweł II: ,godność życia nie wynika jedynie z jego źródeł, czyli z faktu, że pochodzi ono od Boga, ale także z jego celu, z jego przeznaczenia do komunii z Bogiem przez poznanie Go i umiłowanie"18. Godność, o której tu mowa, jest podstawą uzasadniającą dla moralnej normy nienaruszalności życia. W przywołanej przez Jana Pawła II biblijnej historii o Kainie i Ablu Bóg upomina się o krew Abla. Jak zauważa Henryk Witczyk, krew jest tu synonimicznym pojęciem wyrażającym ludzkie życie. Bóg

w kategoryczny sposób zabrania przelewania ludzkiej krwi, ponieważ człowiek zostat stworzony na obraz Boży (Rdz 9,6). W tekście tym „krew ludzka” (symbol życia typowego dla człowieka, odróżnianego od życia obecnego w zwierzętach) stoi w wyraźnym paralelizmie synonimicznym z wyrazem „obraz Boży”. Życie będące jednym z aspektów „obrazu Bożego” w człowieku - winno być chronione i otaczane wszelką możliwą opieką i obroną. Uobecnia ono w człowieku coś z życia samego Boga - jest właśnie jego obrazem, albo inaczej mówiąc symbolem. Tak jak Bóg, jako Bóg żywy, jest święty, tak i człowiek jako istota nosząca w sobie życie, które jest darem (łaską) od Boga pochodzącym, winien być traktowany jako święty w swoim istnieniu ${ }^{19}$.

\section{Kobieta i mężczyzna jako kustosze i kustodie daru życia}

Życie ludzkie, które wyszło z rąk Boga jako święte, zostało powierzone opiece i trosce ludzi. W ten sposób Pan Bóg podzielił się z człowiekiem swoją wyłączną władzą nad życiem ${ }^{20}$. Słowa zapisane w Księdze Rodzaju „Bądźcie płodni i rozmnażajcie się" (Rdz 1,28) wypowiedziane przez Boga do kobiety i mężczyzny są wyrazem zarówno ich wzniosłego powołania do przekazywania życia, jak również nakładają na kobietę i mężczyznę wyjątkową w swoim rodzaju odpowiedzialność za trwanie życia i jego rozwój. Jak zauważa Jan Paweł II w encyklice Evangelium vitae: „,pewien udział człowieka w panowaniu Boga ujawnia się także w szczególnej odpowiedzialności, jaka została mu

${ }^{18} \mathrm{EV} 38$.

${ }^{19}$ H. Witczyk, „Obraz Boży” w człowieku -źródło i cel działania moralnego, w: Antropologia teologicznomoralna. Koncepcje. Kontrowersje. Inspiracje, red. I. Mroczkowski, J.A. Sobkowiak, Warszawa 2008, s. 25.

${ }^{20}$ Por. G. von Rad, Teologia dell'Antico Testamento, t. 1, Brescia 1972, s. 177. 
powierzona w odniesieniu do życia prawdziwie ludzkiego. Najwznioślejszym przejawem tej odpowiedzialności jest przekazywanie życia przez akt zrodzenia, dokonany przez mężczyznę i kobietę w małżeństwie"21.

Misja kobiety i mężczyzny polegająca na ,przekazywaniu życia przez akt zrodzenia" jest fundamentalnym zadaniem, od którego zależy trwanie życia i gatunku ludzkiego. Misja ta, obok swojego ,funkcjonalnego" aspektu, przede wszystkim objawia prawdę o tym, kim są mężczyzna i kobieta, jaki jest sens ich zróżnicowania płciowego przy jednoczesnym ukierunkowaniu wzajemnie na siebie. Właśnie w kontekście rozważań nad życiem, nad jego charakterystyką oraz dynamiką, możemy lepiej zrozumieć właściwy sens kobiecości i męskości, sens, jaki Bóg wpisał w naturę człowieka bytującego w dwoistości płci. Wydaje się, że to właśnie kategoria życia może być niezwykle pomocna w przezwyciężeniu aktualnego kryzysu tożsamości kobiety i mężczyzny, nasilającego się za sprawą zamieszania wywołanego radykalnymi tezami teorii płci kulturowej (ideologii gender).

Encyklika Evangelium vitae, choć nie podejmuje wprost powyższej problematyki, dostarcza nam jednak wielu intuicji antropologicznych i teologicznych, pozwalających na sformułowanie kilku istotnych tez $\mathrm{w}$ nakreślonym temacie.

Mówiąc o przekazywaniu życia jako „najwznioślejszym przejawie odpowiedzialności w odniesieniu do życia prawdziwie ludzkiego", Jan Paweł II przypomniał zamysł Boży względem mężczyzny i kobiety. Bóg „stworzył ich od początku jako mężczyznę i kobietę" (Mt 19,4), gdyż taki sposób istnienia człowieka

- po pierwsze: dawał możliwość odzwierciedlania podobieństwa do Boga, który jest wspólnotą różnych osób tworzących życiodajną komunięe22 (czyniąc w ten sposób zadość Bożemu pragnieniu, aby stworzyć człowieka na obraz Boży zgodnie z Rdz 1,26);

- po drugie: Bóg mógł w ten sposób dać mężczyźnie i kobiecie ,pewne specjalne uczestnictwo w swoim własnym dziele stwórczym"23, co zostało wyrażone błogosławieństwem i misją: „bądźcie płodni i rozmnażajcie się" $(\operatorname{Rdz} 1,28)$. Dla realizacji tego zamiaru konieczna była, jest i będzie konstytutywna różnica płciowa mająca swój wyraz w biologii, psychice i duchowości kobiety i mężczyzny.

${ }^{21} \mathrm{EV} 43$.

${ }^{22}$ Por. Sobór Watykański II, Konstytucja dogmatyczna o Kościele i świecie współczesnym Gaudium et spes, 24, w: Sobór Watykański II, Konstytucje, Dekrety, Deklaracje, Poznań 2002, s. 526-606; Jan Paweł II, List do rodzin Gratissimam sane, Watykan 1994, 8 (dalej: GS).

${ }^{23} \mathrm{EV} 43$. 
Dlatego już Sobór Watykański II zachęcał małżonków, aby odkrywali Boży zamysł względem kobiety i mężczyzny oraz by byli skłonni odważnie i wielkodusznie ,współdziałać z miłością Stwórcy i Zbawiciela, który przez nich wciąż powiększa i wzbogaca swoją rodzinę" ${ }^{24}$. Zrodzenie nowego życia jest $\mathrm{w}$ tej perspektywie postrzegane jako wydarzenie o charakterze zarówno głęboko ludzkim, jak i nadprzyrodzonym. Życie człowieka, które manifestuje się w wymiarach basar, nefes i ruah, swoją wielowymiarowość uwidacznia także w momencie jego przekazywania. Akt zrodzenia dziecka ,angażuje małżonków, tworzących «jedno ciało» (por. Rdz 2,24), a zarazem Boga samego, który jest obecny. [...] Tak więc $\mathrm{w}$ akcie rodzenia, w którym rodzice przekazują życie dziecku, zostaje też przekazany - dzięki stworzeniu nieśmiertelnej duszy - obraz i podobieństwo samego Boga"25.

Tak oto „,W biologię rodzenia wpisana jest genealogia osoby" ${ }^{\prime 26}$, przez co rozumie się, że zrodzony z miłości i jedności dwojga małżonków nowy człowiek ,przynosi ze sobą na świat szczególny obraz i podobieństwo Boga samego" ${ }^{27}$. Wspomniany „akt zrodzenia”, rozumiany jako poczęcie i narodziny człowieka, zostaje dopełniony ,procesem rodzenia", kiedy to podczas jego rozwoju stopniowo ujawniać się będą wszystkie wymiary ludzkiego życia: cielesnego, psychicznego i duchowego. Życie potrzebuje czasu, aby ujawnić na zewnątrz wszystkie wymiary bytowania człowieka (właściwości fizyczne, sprawności psychiczne, wielkość ducha zdolnego kochać podobnie jak Bóg). Pozbawienie życia tej możliwości jest krzywdą wyrządzoną nie tyle życiu, ile wprost człowiekowi, któremu odbiera się szansę osiągnięcia właściwej mu pełni.

Papież przytacza w encyklice Evangelium vitae to niezwykle doniosłe w swej treści zdanie pochodzące źródłowo z napisanego wcześniej Listu do rodzin: „w biologię rodzenia wpisana jest genealogia osoby”28. Wyjaśnia $\mathrm{w}$ nim, jak należy rozumieć wyrażoną $\mathrm{w}$ zacytowanym zdaniu prawdę. Uwzględniając powołanie kobiety i mężczyzny do bycia współpracownikami Boga w dziele przekazywania życia, „sformułowaniem tym nie wskazujemy tylko na prawa biologii, ale na to, że w ludzkim rodzicielstwie Bóg sam jest obecny - obecny w inny jeszcze sposób niż to ma miejsce w każdym innym rodzeniu w świecie widzialnym, «na ziemi». Przecież od Niego tylko może pochodzić «obraz i podobieństwo», które jest właściwe istocie ludzkiej, tak jak przy stworzeniu. Rodzenie jest kontynuacją stworzenia"29. Dlatego też

\footnotetext{
${ }^{24}$ Sobór Watykański II, Gaudium et spes, 50.

${ }^{25} \mathrm{EV} 43$.

${ }^{26} \mathrm{EV} 43$.

${ }^{27}$ EV 43.

${ }^{28}$ GS 9.

${ }^{29}$ GS 9.
} 
winno nazywać się prokreacją, a w żadnym wypadku nie reprodukcją. Terminy te wyraźnie wskazują na zupełnie dwa przeciwstawne światy rozważań o przekazywaniu życia: pierwszy ujmuje życie szeroko we wszystkich jego przejawach i niepowtarzalności dzięki stwórczemu działaniu Boga, z którym współpracują rodzice; drugi redukuje życie wyłącznie do zmian zachodzących w materii, którą daje się rozmnożyć poprzez powielanie, czyli reprodukcję.

We wspomnianym Liście do rodzin papież przypomina małżonkom, że Boża miłość względem życia, Boże „chcę” powiedziane życiu, jest w pewnym sensie paradygmatyczne i normatywne również dla ludzkiej woli stającej wobec tajemnicy życia ${ }^{30}$. Jak powie Jan Paweł II: „trzeba, ażeby w to chcenie Boga włączało się ludzkie chcenie rodziców: aby oni chcieli nowego człowieka, tak jak go chce Stwórca" "31. Noszący w sobie podobieństwo do Boga człowiek, którego własne życie nosi w sobie charakterystykę „trwania ku wieczności", jeśli chce zachować prawdę o sobie i nie popaść w jakąś wewnętrzną sprzeczność, nie może odpowiedzieć inaczej na dar życia jak tylko bogupodobnym „chcę”. To „chcę” powiedziane życiu oznacza jednocześnie akceptację różnicy płciowej będącej koniecznym warunkiem procesu przekazywania życia. Ewentualne ludzkie „nie chcę”, wypowiedziane wobec życia albo wobec kobiecości i męskości, jest tragicznym zaprzeczeniem istoty człowieczeństwa i ludzkiej życiodajności. Zaprzeczenie to w konsekwencji może prowadzić nie tylko do unicestwienia nowo powstałego życia (zamachy na życie poczęte), ale i do powolnego obumierania tego, kto życiu powiedział: „nie chcę". Podobną ,śmiercionośność” zawiera w sobie negacja biologicznie uwarunkowanej różnicy płciowej. Brak integracji i harmonii różnych wymiarów ludzkiej płciowości prowadzi często do jałowej wegetacji zamkniętej na dzielenie się życiem w miłości i prokreacji.

30 „W miłość małżeńską i rodzicielską wpisuje się ta prawda o człowieku, którą tak zwięźle, a tak dogłębnie zarazem wyraził Sobór, mówiąc, że Bóg «chce człowieka dla niego samego». Trzeba, ażeby w to chcenie Boga włączało się ludzkie chcenie rodziców: aby oni chcieli nowego czlowieka, tak jak go chce Stwórca" - GS 9.

Dodatkowe światło rzuca nam w tym kontekście rozważenie słów rytu sakramentu małżeństwa dotyczących przyszłych nowożeńców: „"Czy chcecie z miłościa przyjąc i po katolicku wychować potomstwo, którym Bóg was obdarzy?» - pyta ich celebrans w momencie ślubu. Potwierdzenie ze strony nowożeńców odpowiada wewnętrznej prawdzie miłości, jaka ich łączy. Jedność dwojga nie zamyka małżonków, nie jest dla nich samych. Jest otwarta w kierunku nowego życia i nowej osoby. Małżonkowie jako rodzice są zdolni obdarzyć życiem istotę do nich samych podobną, nie tylko «kość z ich kości i ciało z ich ciała» (por. $R d z$ 2,23), ale obraz i podobieństwo Boga - czyli osobę.

Pytając: «czy chcecie [...] przyjąć», Kościół przypomina nowożeńcom, że oto stają wobec stwórczej mocy Boga. To, że mają stać się rodzicami, oznacza życiodajne współdziałanie ze Stwórcą. Współpracować ze Stwórcą w powołaniu do życia nowych istot ludzkich, to znaczy przyczynić się do przekazania obrazu i podobieństwa Boga, którym staje się każdy «narodzony z niewiasty»" GS 8.

${ }^{31}$ GS 9. 


\section{3. Życie ludzkie w społecznym eksperymencie gender}

Płciowość kobiety i mężczyzny, tak w jej somatycznym, psychicznym, jak i duchowym wymiarze, ma doniosłą funkcję, gdyż w niej i przez nią wyraża się i trwa życie człowieka ${ }^{32}$. Dzięki zróżnicowaniu płciowemu kobieta i mężczyzna, zjednoczeni w małżeństwie, mogą zostać włączeni w działanie Boże. Przez akty poczęcia, zrodzenia i wychowania dzieci rodzice sprawiają, że Boży dar życia zostaje przyjęty i w ten sposób buduje się przyszłość pełna nadziei. Nowe życie otwiera się na przyszłość, a przyszłość gwarantowana jest nowym życiem ${ }^{33}$. Tak właśnie realizuje się dobra nowina o życiu - Ewangelia życia.

Już w trakcie refleksji prowadzonej w poprzedniej części niniejszego opracowania mogliśmy się zetknąć z wyszczególnieniem pewnych niepokojących tendencji, które stoją $\mathrm{w}$ sprzeczności $\mathrm{z}$ podstawowym powołaniem kobiety i mężczyzny jako kustoszy życia. Szczególne skupienie tych tendencji zaobserwować możemy w programowanych i kontrolowanych procesach społecznych, które umownie nazwijmy ,eksperymentem gender".

Eksperyment ten w bardzo dużej ogólności określić możemy jako wieloaspektowe wpływanie poprzez kształtowanie prawa i inne działania instytucjonalne na mentalność oraz obyczajowość całych społeczeństw w kwestii rozumienia kobiecości i męskości oraz ról społecznych przypisywanych płciom, interpretowanych w kluczu wypracowanej zasadniczo w środowiskach feministycznych i niehetroseksualnych teorii tzw. płci społeczno-kulturowej ${ }^{34}$.

Centralną kategorią analityczną tej teorii jest pojęcie gender, które służy m.in. do określenia społeczno-kulturowych wzorców płci oraz ról, jakie kultura przypisuje odpowiednio mężczyznom i kobietom. W skrócie: gender w naukach społecznych to zespół cech, postaw i ról przypisywanych kobiecie i mężczyźnie przez kulturę ${ }^{35}$. Ważne jest to, że społeczno-kulturowe rozu-

32 Por. Kongregacja Doktryny Wiary, Persona humana, Wrocław 1993, 1.

${ }^{33}$ Por. EV 43.

34 Pojęcie gender pojawiło się w dokumentach międzynarodowych za sprawą Konferencji Kobiet w Pekinie zorganizowanej pod egidą ONZ w 1995 roku. Dokument końcowy tej konferencji „Platforma Działania” wprowadził na stałe pojęcie gender (jako płci społeczno-kulturowej) do języka ONZ, prawa międzynarodowego i polityki społecznej. W dokumencie tym domagano się włączenia problematyki równości płci do głównego nurtu polityki społecznej prowadzonej czy to na szczeblu lokalnym, czy globalnym. Ratyfikowany dokument przez głowy licznych państw świata stał się wiążący m.in. dla prawodawstwa Unii Europejskiej i jej polityki równościowej i antydyskryminacyjnej.

35 Jest jeszcze kilka innych znaczeń przypisywanych pojęciu gender, np: (1) gender jako „interpretacja płci biologicznej, stosowana w odniesieniu do społecznego charakteru różnic między kobietami i mężczyznami”; (2) gender jako „warstwa tożsamości (współistniejąca z innymi cechami, takimi jak rasa, klasa, wiek)"; (3) gender ,jako relacja (relacje) władzy w społeczeństwie patriarchalnym”; (4) gender jako „dyskursywny system regulacji i kontroli ciał i zachowań”. Por. M. Grabowska, Od „gender do „transgender”: ewolucja kategorii płci społeczno-kulturowej 
mienie płci mniej lub bardziej oddziela się od biologicznych determinant płci, określanych słowem sex. Im bardziej interpretacje płci separują wymiar kulturowy od wymiaru biologicznego, osiągają coraz bardziej radykalną postać. Nurty mniej radykalne, określane czasem jako „miękki” konstruktywizm ${ }^{36}$, dopuszczają tradycyjny podział na dwie płcie, koncentrując swą uwagę na likwidowaniu dyskryminującej różnicy wytwarzanej kulturowo w postrzeganiu ról kobiecych i męskich. Bardziej zradykalizowane środowiska „twardego" konstruktywizmu, bazując na teoretycznych rozważaniach, np. Judith But$\operatorname{tler}^{37}$, dążą do zanegowania naturalnej, biologicznie uwarunkowanej, różnicy płciowej, upatrując w kulturze i procesach społecznych jedyne źródło „wytwarzania" płci (gender).

Wypracowana głównie w feministycznych środowiskach tzw. gender studies teoria gender balansuje na krawędzi ideologii, a czasem przyjmuje wprost jej postać, w celu sformułowania praktycznego programu przebudowy postrzegania ludzkiej płciowości ${ }^{38}$.

Ideologizacja analitycznej kategorii gender polega m.in. na tym, że posługując się tym terminem, usiłuje się narzucić taką interpretację ludzkiej płciowości, w której pomniejsza się znaczenie naturalnej (biologicznej) różnicy płciowej, np. celowości ludzkich narządów rozrodczych (która to celowość jest podstawą dla zrozumienia heteroseksualnej normatywności), wszystko thumacząc wzorcami kulturowymi i społecznie wykreowanymi schematami zachowań. Otwiera to drogę do lansowania poglądu o względności matrycy heteroseksualnej i promuje wizję różnorodności i wielości równouprawnionych orientacji seksualnych. Aby osiągnąć zamierzone cele, pewne środowiska (m.in. mniejszości seksualne) przystąpiły do edukacyjnej ofensywy, wprowadzając do przestrzeni publicznej szereg nowych terminów, takich jak np. homofobia czy mowa nienawiści, a także żądając wprowadzenia modelu genderowej interpretacji płci do szkolnych programów nauczania ${ }^{39}$, politycznych strategii antydyskryminacyjnych $^{40}$ czy też do stanowionego prawa państwowego i międzynarodowego ${ }^{41}$.

w naukach spolecznych i prawie międzynarodowym, s. 2, http://rownosc.info/media/uploads/ biblioteka/publikacje/od_gender_do_transgender_tekst.pdf [dostęp: 11.02.2017].

${ }^{36}$ Rozróżnienie na „miękki” '- „twardy” konstruktywizm w odniesieniu do zróżnicowania nurtów interpretacyjnych w ramach teorii gender przytaczam za: M. Grabowska, Od ,gender..., s. 21-24.

${ }^{37}$ Por. J. Buttler, Uwikłani w płeć, tłum. K. Krasuska, Warszawa 2008.

${ }^{38} \mathrm{Na}$ ten temat pisałem m.in. w artykule pt. Ideologia gender $w$ świetle ekologii integralnej papieża Franciszka, „Studia Bydgoskie” 10 (2016), s. 79-104. Przytaczam z tamtego artykułu fragmenty pomocne w zrozumieniu omawianej aktualnie problematyki.

${ }^{39}$ Por. G. Amato, Gender (d)istruzione. Le nuove forme d'indottrinamento nelle scuole italiane, Verona 2015.

${ }^{40}$ D. O'Leary, Maschi o femmine? La guerra del genere, Soveria Mannelli 2006, s. 27-39.

${ }^{41}$ Por. G. Kuby, Globalna rewolucja seksualna. Likwidacja wolności w imię wolności, Kraków 2013, s. 99-122. 
W procesie ideologizacji analitycznej kategorii gender obok marksizmu wpływową rolę odegrał myślowy klimat postmodernizmu. Charakterystyczny dla tego nurtu relatywizm, brak pewników, zwątpienie w metafizykę i w prawdę, odrzucenie realizmu poznawczego, a zwłaszcza założenia poststrukturalistyczne i rozważania na temat teorii władzy ${ }^{42}$ przyczyniły się do wzmocnienia wyłącznie kulturowej interpretacji fenomenu płci. W myśl tych interpretacji płeć nie ma charakteru stałego, zakotwiczonego w biologii, lecz jest ciągle odgrywana, inscenizowana według scenariusza pisanego przez narzucane ludziom przez innych ludzi wzorce kulturowe i narracje ${ }^{43}$. A skoro tak jest, to wzorce te możemy swobodnie zmieniać, wyzwalać się od wzorców narzucanych przez innych, kreować własną interpretację swojej płci (teoria performatywności płci). W ten oto sposób otwarta została furtka do polimorfizmu zachowań seksualnych, z których wszystkie mają równe prawo do zamanifestowania się w społeczeństwie, gdyż tak, jak wielu jest ludzi na świecie, tak wiele może być form przeżywania ich własnej płciowości.

Jak powie Buttler, jedynie istniejąca płeć, czyli płeć kulturowa - gender, ma charakter performatywny, co oznacza, że „można performatywnie pomnożyć liczbę jej konfiguracji, wychodząc poza restrykcyjne ramy maskulinistycznej dominacji i obowiązkowej heterseksualności" ${ }^{44}$.

W ideologii gender zupełnie na margines odsunięta została kwestia związku płci z życiem rozumianym jako cielesno-psycho-duchowy proces istnienia osoby. Spowodowane jest to arbitralną decyzją o uznaniu płci za fenomen czysto kulturowy. Jeśli mówi się w tej perspektywie o życiu, to raczej w znaczeniu satysfakcji z „życia seksualnego”, prawa do „zdrowia reprodukcyjnego” czy „zabezpieczenia się" przed poczęciem nowego życia. Jednak już w samych tych sformułowaniach widzimy odniesienia się do cielesnego wymiaru płci, co wyraźnie zadaje kłam lansowanej w skrajnym genderyzmie tezie o wyłącznie kulturowym charakterze płci. Owszem, płeć ma swoje uwarunkowania i manifestacje w kulturze, ale ma także wymiar cielesny, który wyraża się w biologii płci. Chcąc całościowo ujmować fenomen płci, nie można nie zauważać, że splata się ona tak wyraźnie z dynamizmem życia. Życie ludzkie w jego wielowymiarowości (cielesno-psycho-duchowej) przybiera postać konkretnych osób istniejących na sposób płciowy (również cielesny), a sama płciowość jest tym wymiarem ludzkiej egzystencji, który- także dzięki biologii - warunkuje przede wszystkim ciągłość istnienia ludzkości. Przypominamy w tym miejscu sprawę oczywistą - a niestety wyraźnie pomijaną w ideologii gender - że biologiczny wymiar płci jest warunkiem sine qua non istnienia i przekazywania

\footnotetext{
${ }^{42}$ Por. R. Connell, Questioni di genere, Urbino 2011, s. 141-144.

${ }^{43}$ Por. L. Palazzani, Sex/gender: gli equivoci dell'ugualianza, Torino 2015, s. 76-85.

${ }^{44}$ J. Buttler, Uwiktani ..., s. 254.
} 
życia. Proces ten zagwarantowany jest poprzez zróżnicowanie płciowe, wyrażające się w istnieniu kobiet i mężczyzn.

Przeprowadzona wyżej refleksja miała zachęcić do pochylenia się nad wyjątkową misją kobiety i mężczyzny jako kustoszy Ewangelii życia. Nie chodziło tu jednak o przypomnienie dobrze już znanych treści teologii małżeństwa i rodziny, lecz o zaproponowanie pewnej drogi myślowej, która wychodząc od analizy wielowymiarowości ludzkiego życia, ukaże fundamentalną i niezbywalną rolę komplementarności płci w procesie jego przekazywania i trwania. Warto zauważyć pewną interesującą prawidłowość: nie tylko płeć warunkuje trwanie życia, ale również życie jako proces warunkuje właściwe zrozumienie płci, a zwłaszcza jej binarnej natury. Fenomen życia rozumianego jako złożonego procesu cielesno-psycho-duchowego może być kluczem do ponownego odkrycia głębi tożsamości kobiety i mężczyzny w obliczu kryzysu wywołanego radykalnymi tezami ideologii gender.

W niniejszym opracowaniu staraliśmy się pokazać, że istnieje ścisła analogia pomiędzy sposobem pojmowania samego życia a stosunkiem do jego przekazywania. Redukcjonizm w rozumieniu fenomenu życia (materializm) prowadzi do redukcjonizmu w spojrzeniu na prokreację, którą zaczyna traktować się jako „reprodukcję”. Wpływa to dalej na zachwianie się poczucia wzniosłości powołania kobiety i mężczyzny, którzy tracą świadomość swej wyjątkowej misji i gubią fascynację płynącą z faktu bycia włączonymi w najwspanialszy proces, jaki dzieje się na ziemi - proces trwania życia. W konsekwencji bardziej interesujące dla mężczyzn i kobiet staje się bycie aktywnymi na polu przekształcania rzeczy i instytucji, aniżeli włączenie się w Boży projekt biologii rodzenia, w którą wpisana jest genealogia osoby.

A przecież ten Boży projekt zawierzony został kobiecie i mężczyźnie uzdolnionym odpowiednio do tego, by dar życia tętniący w nich samych, był przekazywany dalej. Komplementarność płci, prowadząca do oblubieńczego spotkania kobiety i mężczyzny w płodnej miłości małżeńskiej, stwarza swoistą, wyjątkową i niczym niezastępowalną ,przestrzeń” dla narodzin i rozwoju życia: nowego życia konkretnych osób i życia jako cudownego procesu będącego „dobrą nowiną o istnieniu”. Oznacza to, że kobieta i mężczyzna są przede wszystkim niezastąpionymi kustoszami Ewangelii życia, co wymaga od nich pogłębiania świadomości tej tożsamości i wierności zadaniom, jakie wiążą się z ich misją w świecie.

Mężczyzna i kobieta całymi sobą - w ich zróżnicowaniu somatycznym, psychicznym i duchowym - wskazują na swoją podstawową misję bycia także kustodiami życia. Życie objawia się w konkretnej osobie jako „ucieleśnio- 
ne" w postaci kobiecej lub męskiej. To właśnie tętniące w kobiecie i mężczyźnie życie sprawia, że lgną oni do siebie i tak są stworzeni, aby ich bliskość mogła stać się życiodajna dla nich samych oraz dla ich potomstwa, z którym podzielą się życiem. W tym właśnie ,udzielaniu życia” uwidacznia się rys podobieństwa człowieka do Boga (dzielenie się życiem) i udział w Bożej władzy nad życiem (panowanie nad życiem w znaczeniu rozumnego ukierunkowania popędu seksualnego zgodnie z jego celowością).

Przekazywanie życia możliwe jest dzięki różnicy płciowej chcianej od początku przez Boga, co wyraża się na wiele sposobów, a między innymi $\mathrm{w}$ fascynującej tajemnicy trwania życia dzięki przekazywanemu w procesie prokreacji kodowi genetycznemu pochodzącemu ze zróżnicowanych płciowo komórek rozrodczych kobiety i mężczyzny. Każdy, kto choć w nieznacznym stopniu przeanalizuje somatyczne uwarunkowania różnicy płciowej, zwłaszcza te dotyczące układu rozrodczego, odkryje, w jaki sposób istnienie tej odmienności gwarantuje ciągłość życia. Komplementarność kobiety i mężczyzny, prowadząc do zjednoczenia w miłości (we wszystkich jej przejawach, nie wykluczając cielesnego), funduje małżeństwo będące swoistą kustodią życia. Kustodia ta, jako przestrzeń poczęcia i zrodzenia życia, jest z konieczności naznaczona pierwiastkiem kobiecości i męskości, które sprawiają, że pojawiające się na świecie nowe życie - nowy człowiek - od samego początku spotyka się z dwoistością płci, która na zawsze będzie tworzyła jego egzystencjalne otoczenie. Deprecjonowanie binarnej różnicy płciowej, uważanie jej za wytwór jedynie kultury, negowanie jej czy nieliczenie się z jej realnym istnieniem, sprzeczne jest z powszechnym doświadczeniem i prowadzi w konsekwencji do intelektualnego obłędu w porządku poznawczym, a ludzki gatunek stawia w obliczu ryzyka stopniowego wymierania aż po tragedię samounicestwienia.

Przez prokreację i troskę o życie kobieta i mężczyzna mogą wyrazić swoją miłość do życia, przez co dają wyraz podobieństwa człowieka do Boga - miłośnika życia (por. Mdr 11,26). Tę miłość ku życiu Stwórca zaszczepił w serce kobiety i mężczyzny, którzy lgną ku sobie i pragną miłosnego zjednoczenia, widząc w nim życiodajną bliskość. Miłosne zjednoczenie jest twórcze, życiodajne i płodne dla nich samych: wzajemna miłość stwarza ich na nowo, czyniąc z mężczyzny męża, a z kobiety żonę. Ma też moc obdarować życiem nową istotę ludzką, a małżonków po raz kolejny stworzyć na nowo: jako ojca i matkę.

Mogliśmy się przekonać jak bardzo radykalne tezy ideologii gender stoją w sprzeczności z Ewangelią życia. Niszcząc realną koniunkcję pomiędzy rolą płciową a biologicznymi determinantami płci, genderyzm wyrywa ludzką seksualność z kontekstu prokreacji, czyniąc z niej jedynie źródło przyjemności i egoistycznego zaspokojenia. Taka wizja ludzkiej płciowości nie tylko 
sprzeczna jest z Bożym zamysłem wpisanym w naturę kobiety i mężczyzny, ale również uwłacza godności osoby ludzkiej i odziera ją z najbardziej wzniosłych atrybutów człowieczeństwa, jakimi są: odpowiedzialność za życie, zdolność jego przekazywania i spełnienie kobiecości i męskości w płodnej miłości.

Niebezpieczeństwo płynące ze strony ideologii gender dostrzegają także reprezentanci nieteologicznych nauk o człowieku. Jak zauważa cytowana przez Josepha Meany'ego Katarina Runske, ,z biologicznego punktu widzenia nic tak nie ujawnia nieprzystosowania organizmu do życia, jak brak prostej zastępowalności pokoleń. Ponieważ feminizm prowadzi do natychmiastowego spadku demograficznego, narody przyjmujące ideologię feministyczną, czynią to ku własnej zgubie"45.

Zarysowane $\mathrm{w}$ niniejszym wystąpieniu napięcie pomiędzy wzniosłością powołania kobiety i mężczyzny głoszonego w chrześcijaństwie a destrukcyjnym sprymitywizowaniem wizji ludzkiej płciowości w ideologii gender budzi odwagę do zdecydowanego przeciwdziałania często zamaskowanym symptomom cywilizacji śmierci. Może to się dokonywać na wielu płaszczyznach. Wymienię tylko niektóre. Oto one:

1) demaskowanie fałszu tkwiącego w zbiegu odrywania kultury od natury;

2) postrzeganie kobiecości i męskości w kontekście życia, które tętni w kobiecie i mężczyźnie oraz w życiodajnej wspólnocie, którą mogą stworzyć: misterium życia tłumaczy znaczenie i rolę płci;

3) zgłębianie teologii ciała (wkład Karola Wojtyły);

4) ponowne odkrycie i promocja piękna i doniosłości prokreacji;

5) przeciwdziałanie inwazji edukatorów genderowych i czuwanie nad zmianami legislacyjnymi, aby były promocją kultury życia.

Na zakończenie przywołajmy wymowne słowa św. Jana Pawła II, który przestrzegał, że „banalizacja płciowości jest jednym z czynników, które stoją u początków pogardy dla rodzącego się życia: tylko prawdziwa miłość umie strzec życia" ${ }^{\prime \prime}$.

45 J. Meany, Feministyczny atak na ojcostwo, w: Międzynarodowy Kongres „O godność ojcostwa”, red. E. Kowalewska, Gdańsk 2000, s. 142.

${ }^{46}$ EV 97. 


\section{WOMAN AND MAN AS CUSTODIANS OF THE GOSPEL OF LIFE IN THE CONTEXT OF A SOCIAL GENDER EXPERIMENT}

\section{Summary}

The analysis of the mystery of life can be helpful to overcome the current crisis of woman's and a man's sexual/gender identity caused by radical theses of the gender ideology. In the light of biblical anthropology we can know better the multidimensional nature of human life. The life-cycle mystery is closely linked with the process of life transmitting. The woman and man have received from God the capability and mission to transmit life. This ability inscribed in the nature of the person expresses the essential feature of their vocation as beings created in the image of God. Woman and man should to be life-giving, as God is the life-giving Creator. The negation of this life-giving aspect of human nature present in the radical theses of gender ideology places this theory in obvious contradiction to the Gospel of life. For this reason the gender ideology can be considered as a serious threat not only to individual man but to all human family.

Słowa kluczowe: ideologia gender; ludzkie zycie; prokreacja; tożsamość płciowa; kobieta i mężczyzna

Keywords: gender ideology; human life; procreation; sexual/gender identity; woman and man

\section{BIBLIOGRAFIA}

Amato G., Gender (d)istruzione. Le nuove forme d'indottrinamento nelle scuole italiane, Verona 2015.

Bosetti E., Il mistero della vita e la sua rivelazione nella Sacra Scrittura, w: Lo splendore della vita: Vangelo, scienza ed etica. Prospettive della bioetica a dieci anni da Evangelium vitae, red.

L. Melina, E. Sgreccia, S. Kampowski, Città del Vaticano 2006, s. 35-51.

Buttler J., Uwiktani w pteć, tłum. K. Krasuska, Warszawa 2008.

Connell R., Questioni di genere, Urbino 2011.

Grabowska M., Od „gender do „transgender”: ewolucja kategorii plci spoleczno-kulturowej w naukach spolecznych i prawie międzynarodowym, s. 2, w: http://rownosc.info/media/uploads/ biblioteka/publikacje/od gender do transgender tekst.pdf [dostęp: 11.02.2017].

Mroczkowski I., Starotestamentalne rozumienie ciała, duszy i ducha człowieka, „Studia Płockie” 21(1993), s. 17-24.

Jan Paweł II, Encyklika Evangelium vitae, Kraków 1995.

Jan Paweł II, List do rodzin Gratissimam sane, Watykan 1994.

Jan Paweł II, Katechizm Kościoła Katolickiego, Poznań 1994.

Jan Paweł II, Encyklika Redemptor hominis, Wrocław 1986.

Keiser O., Der Gott des Alten Testaments: Wesen und Wirken. Theologie des AT 2, Göttingen 1998.

Kongregacja Doktryny Wiary, Persona humana, Wrocław 1993. 
Kuby G., Globalna rewolucja seksualna. Likwidacja wolności w imię wolności, Kraków 2013.

Meany J., Feministyczny atak na ojcostwo, w: Międzynarodowy Kongres „O godność ojcostwa”, red. E. Kowalewska, Gdańsk 2000, s. 139-146.

Muszala A., Koncepcja czlowieka wedlug św. Pawła i jej implikacje dla bioetyki, w: K. Jasiński, Z. Kieliszek, M. Machinek, Mózg - umyst - dusza. Spór o adekwatna antropologię, Olsztyn 2014, s. 125-140.

O’Leary D., Maschi o femmine? La guerra del genere, Soveria Mannelli 2006.

Olczyk M., Ideologia gender w świetle ekologii integralnej papieża Franciszka, „Studia Bydgoskie” 10 (2016), s. 79-104.

Palazzani L., Sex/gender: gli equivoci dell'ugualianza, Torino 2015.

Schockenhoff E., Etyka życia. Podstawy i nowe wyzwania, tłum. K. Glombik, Opole 2014.

Sobór Watykański II, Gaudium et spes, 24, w: Sobór Watykański II, Konstytucje, dekrety, deklaracje, Poznań 2002, s. 526-606.

von Rad G., Teologia dell'Antico Testamento, t. 1, Brescia 1972.

Witczyk H., „Obraz Boży” w człowieku - źródto i cel działania moralnego, w: Antropologia teologicznomoralna. Koncepcje. Kontrowersje. Inspiracje, red. I. Mroczkowski, J.A. Sobkowiak, Warszawa 2008, s. 19-37.

Wolff H.W., Anthropologie des Alten Testaments, München 1990.

MACIEJ OlCzYK, ks. dr hab. prof. UAM, jest pracownikiem naukowym w Zakładzie Teologii Moralnej, Duchowości i Katolickiej Nauki Społecznej na Wydziale Teologicznym Uniwersytetu im. A. Mickiewicza w Poznaniu. Prowadzi badania w zakresie etyki teologicznej. Autor publikacji z zakresu teologii moralnej fundamentalnej, antropologii teologicznej, teologii małżeństwa i rodziny, bioetyki oraz etyki seksualnej. W swoich pracach nawiązuje do aktualnych problemów społecznych, dylematów etycznych i zachodzących przemian obyczajowych 